\title{
Analysis of Tall Building with Different Lateral Force Resisting System
}

\author{
Karthik, A., Ankit Batra, Sakshi Gupta
}

\begin{abstract}
In the current circumstance, the populace is expanding rapidly, thus, the urban areas are becoming wide by devouring farming and green space and the land esteem is expanding. Another point is the tall vertical structure speaks to the country. As it builds the notoriety of the nation. To keep away from this the structures began developing vertical and thin as it arrives at a specific height the wind force governs the building as the main load more than gravity load, as the building grows higher the stability reduces. Due to a lack of design to face wind loads, as the cross-section decreases the stability reduces. And these structures are more prone to earthquakes and wind. Therefore, much research is proceeding to balance out the structure from an increasingly affordable perspective. To know the best performance and economical for the lateral force-resisting system of different types of 30 story buildings are modelled in ETABS, assuming the site location as BHUJ Gujarat, India. For the different structural systems that are compared for minimum story displacement and minimum story drift, these are the qualities that characterize the human comforts for the structure. the structural system used is conventional, shear wall, truss belt, outrigger, diagrid, and fluid viscous damper are used to compare the best performance of the structure. Above all diagrid and viscous damper shows the less displacement and drift values when compared to others but from the economic point of view viscous damper gives the best result from all the above.
\end{abstract}

KEYWORDS- Conventional, Shear-wall, Truss-belt, Outrigger, Diagrid, Viscous damper, Response spectrum, ETABS

\section{Manuscript received May 21, 2020}

Karthik, A., Student of M.Tech Structural Engineering in the Department of Civil Engineering, Amity School of Engineering and Technology, Amity University Haryana, India (email : karthiknayak2051995@gmail.com)

Ankit Batra, Assistant Professor, Department of Civil Engineering, Amity School of Engineering and Technology, Amity University Haryana, India

Sakshi Gupta, Assistant Professor, Department of Civil Engineering, Amity School of Engineering and Technology, Amity University, Haryana, India

\section{INTRODUCTION}

The populace in the urban areas is expanding every day, accordingly, the expense of land is increasing and vegetation is diminishing, because of diminished vegetation contamination is expanded, in this circumstance, new development strategies are rehearsing to defeat all the issues on tall building development. At the point when the tall structure begins developing higher, they began confronting numerous issues like material selection, wind and earthquake governing, and other factors. From the structural point of view when the high-rise building started growing, they faced a lot of structural stability issues governed by wind and ground motions. To stable, the new structural systems are started practicing like a shear wall, belt truss, outrigger, diagrid, and other structural stability systems. So, it is important to know how these structures behave during wind and earthquake. The tall structures have been begun mostly for business space at that point, later on, it began embracing to private and blended-use space. Numerous tall structures have come in to practice from the park row building in 1899 started with a height of $119 \mathrm{~m}$ to Bhuj Kalifa in 2009 rising to $828 \mathrm{~m}$ in height (Figure 1), these shows that how the construction techniques are developed from past recent years $[1][2][3][4]$.

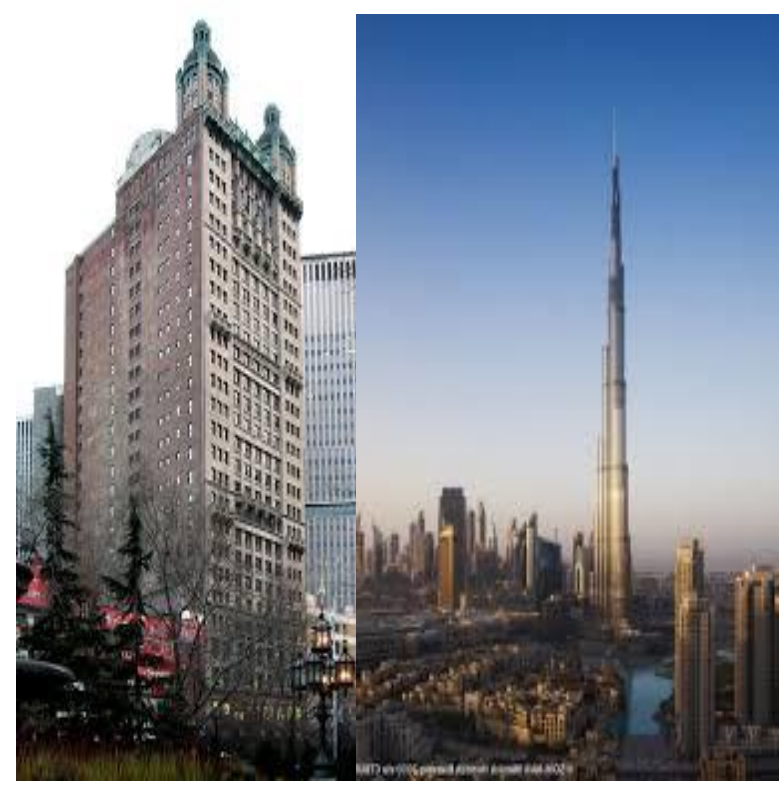

Fig 1: Park building \& Bhuj Khalifa [5] 


\section{AIM AND OBJECTIVES}

The aim is to study the behavior of different lateral force resisting systems in tall structures.

The objective of this study is to:-

- Analysis of the tall building with different lateral force resisting system to find out the parameters like displacement, drift, and time period.

- Comparing the diagrid lateral force resisting system with a damper system provided at different locations.

\section{LITERATURE REVIEW}

Numerous speculations have been proposed to explain how the structure behaves under lateral force. Although the literature review covers a wide variety of theories, this will review will focus on some major aspects on how the different type of structure will act under the influence of lateral force and other things like the importance of the structural system in tall structures how the building will act with and without lateral stability systems and how they influence the economy and the future trends.

- Raju and Reddy (2019). Worked on how the shear wall in a building increases performance. He has given complete details on how the shear wall plays an important role in the seismic zone and how to place the shear wall economically in the building [6].

- Bhavsar et al. (2019). worked on how the story displacement is reduced due to the shear wall, how the shape of the shear wall will affect the building performance both in $\mathrm{X}$ and $\mathrm{Y}$ direction, and the increase in the percentage of the shear wall how it will influence the stiffness of the building [7].

- Kala et al. (2017). worked on how the outrigger and truss belt system influence on lateral behavior of the structure and the optimum location of the outrigger and truss belt system under the wind load is $0.25-0.33$ times the height of the building for the wind loads [8].

- Khanorkar et al. (2016). worked on the various techniques and methods used to investigate the uses of truss belts and outriggers in tall structures. He differentiated the deflection criteria and bending moment criteria [9].

- Tavakoli et al. (2019). worked on the analysis of the outrigger and truss belt system and how the soil structure interaction effects on the best location of the truss belt and outrigger system also analysis is done for inelastic analysis for both with a fixed base and with soil-structure interaction [10].

- Ganatra et al. (2017). worked on 50 story outrigger system for varying depth. For 50 story building decrease in depth of outrigger in building to $2 / 3 \mathrm{rd}, 1 / 3 \mathrm{rd}$. and $1 / 2$ reduces the lateral displacement up to $3 \%-4 \%$ and $5 \%-6 \%$. and also worked not only on how to control lateral displacement but also on how to control inter-story drift [11].

- Shah et al. (2016). Has analyzed a work on the behavior of outriggers in tall buildings, from the work it is known that by using the virtual outrigger it reduces the load on the structure and structurer made economical, and by seeing the comparison from the virtual outrigger to conventional outrigger with truss belt, a combination of outrigger and truss belt perform better [12].

- Somvanshi et al. (2019). Has worked on comparison on orthogonal and diagrid structure concluded that the diagrid structures have a lesser time period when compared to orthogonal and the cost is the same for both the structural system [13].

- Moon (2016) worked on the design of the diagrid structural system he has concluded that the varying angle of diagrid configuration can produce a different result for tall structures under lateral loads and it can be known that the importance of the diagrid structural system in high rise building [14].

- Kachchhi et al. (2019), has done work on comparative analysis on diagrid with another structural system, form the study it is concluded that the diagrid performs better than other structural system and also discussed how it affects the increase in base shear in diagrid structural system [15].

- Lee et al. (2010). Has analyzed a diagrid for the tall building based on the optimized diagrid angle and to understand the global diagrid mechanism by using the topological technique [16].

- Cetin et al. (2019). Has analyzed a work on the optimal design of viscous damper in structure to reduce the lateral force, as it can decrease the amplitude of the building, and it can be concluded that the differential evolution algorithm can be used to solve the damper problem [17].

- Sajjan et al. (2016). Worked on how the viscous damper will affect the multi-story building as it reduces the lateral displacement and the weight of the building will be slightly higher by using viscous damper by comparing to the conventional model.

- Infanti et al. (2008). has worked on how the damper will affect the high-rise building, by the use of viscous damper it will significantly reduce the lateral force in the building by saving the huge amount of cost and by analyzing with performance-based design [18].

\section{METHODOLOGY}

This section will give the framework of research techniques that are followed in this examination, it gives the data on how the information is gathered to play out the investigation, in this model shear wall, truss belt, outrigger, diagrid, and viscous damper are considered, these auxiliary frameworks are displayed in ETABS to fulfil the aim and objectives. Much research has been done to know the performance of diagrid and other structural systems but here we will be discussing how all the structures will behave and by choosing the best performance while comparing them to each other by drift, displacement, time period, and consumption of steel.

\section{A. Fundamental Assumptions for Analysis}

- The material of the structure is continuous and elastic.

- The relation between stress and strain is linear.

- The deformation of the building is caused due to the applied loads are small and do not change the original design diagram.

- The superposition principle is applicable. 


\section{B. Assumptions for Modelling}

- Analysis components are lined up with the highest points of steel bars in floors in this way overlooking the little counterbalances in the focus line between light emissions profundity.

- The horizontal offset of edge beams is usually small enough to be ignored.

- All columns are typically modeled as being co-linear along their centerline.

- Small offsets of columns from grids are typically ignored in design.

- To ensure that all the lateral loading is carried by the braced or moment frame, it is typical to assume that all they are columns not in braced bays or moment frames are pinned at each floor level, so they do not attract lateral loads.

\section{Parameters of The Model}

Table 1 depicts the parameters used in the current study.

Table 1: Parameter of the model

\begin{tabular}{|c|c|}
\hline $\begin{array}{l}\text { Material } \\
\text { Property } \\
\end{array}$ & Details \\
\hline Grade of steel & $\mathrm{Fe} 250$ \\
\hline $\begin{array}{l}\text { Grade of } \\
\text { concrete }\end{array}$ & M25 \\
\hline $\begin{array}{l}\text { Section } \\
\text { Property }\end{array}$ & \\
\hline Slab & $150 \mathrm{~mm}$ \\
\hline \multirow[t]{2}{*}{$\begin{array}{c}\text { Size of } \\
\text { Columns }\end{array}$} & Varies \\
\hline & $\begin{array}{c}\text { Steel square column from } \\
600 \times 600 \times 80 \mathrm{~mm} \text { to } \\
800 \times 800 \times 60 \mathrm{~mm} \\
\end{array}$ \\
\hline Size of Beam & ISMB 500 for all the models \\
\hline $\begin{array}{l}\text { Shear wall } \\
\text { thickness }\end{array}$ & $250 \mathrm{~mm}$ \\
\hline $\begin{array}{c}\text { Truss Belt } \\
\text { system }\end{array}$ & BRC $120 X 20$ \\
\hline $\begin{array}{c}\text { Outrigger } \\
\text { System }\end{array}$ & BRC $120 X 20$ \\
\hline $\begin{array}{l}\text { Diagrid } \\
\text { System }\end{array}$ & $\begin{array}{l}\text { Dia Pipe of } 180 \times 40 \mathrm{~mm} \text { at the } \\
\text { Bottom storey \& } 130 \mathrm{X} 25 \mathrm{~mm} \text { at } \\
\text { the Upper storey. }\end{array}$ \\
\hline $\begin{array}{l}\text { Viscous } \\
\text { Damper }\end{array}$ & FVD 500 \\
\hline Area & \\
\hline $\begin{array}{c}\text { Total Area of } \\
\text { Building }\end{array}$ & $9720 \mathrm{~mm}^{2}$ \\
\hline \multicolumn{2}{|l|}{ Height } \\
\hline $\begin{array}{c}\text { Total Height of } \\
\text { Building }\end{array}$ & $90 \mathrm{~m}$ \\
\hline No of Stories & 30 \\
\hline $\begin{array}{c}\text { Floor to Floor } \\
\text { Height }\end{array}$ & $3 \mathrm{~m}$ \\
\hline Location & Bhuj, Gujarat \\
\hline
\end{tabular}

\begin{tabular}{|c|c|}
\hline Building Type & Office Building \\
\hline Soil Type & $\begin{array}{c}\text { Medium, type 2 confining to is } \\
\text { 1893-part 1 }\end{array}$ \\
\hline Dead Load & $\begin{array}{c}\text { Self-wight is automatically } \\
\text { considered in ETABS }\end{array}$ \\
\hline Floor Finish & $1.5 \mathrm{kN} / \mathrm{m}^{2}$ \\
\hline Live Load & $2.5 \mathrm{kN} / \mathrm{m}^{2}$ IS 875 Part 2 \\
\hline $\begin{array}{c}\text { Earthquake } \\
\text { Load }\end{array}$ & IS 1893 Part $1-2016$ \\
\hline Wind Load & IS 875 Part 3-2015 \\
\hline $\begin{array}{c}\text { Displacement } \\
\text { check }\end{array}$ & $\mathrm{H} / 500 \mathrm{~mm}$ \\
\hline Drift check & $<0.004$ \\
\hline
\end{tabular}

\section{Models}

\section{a. Conventional System}

In the conventional structural system, all the frame members are of special moment resisting frame with no additional lateral force resisting system is considered, considering the conventional system as a reference for comparing to other lateral force resisting system to find out the objectives (Figure 2).

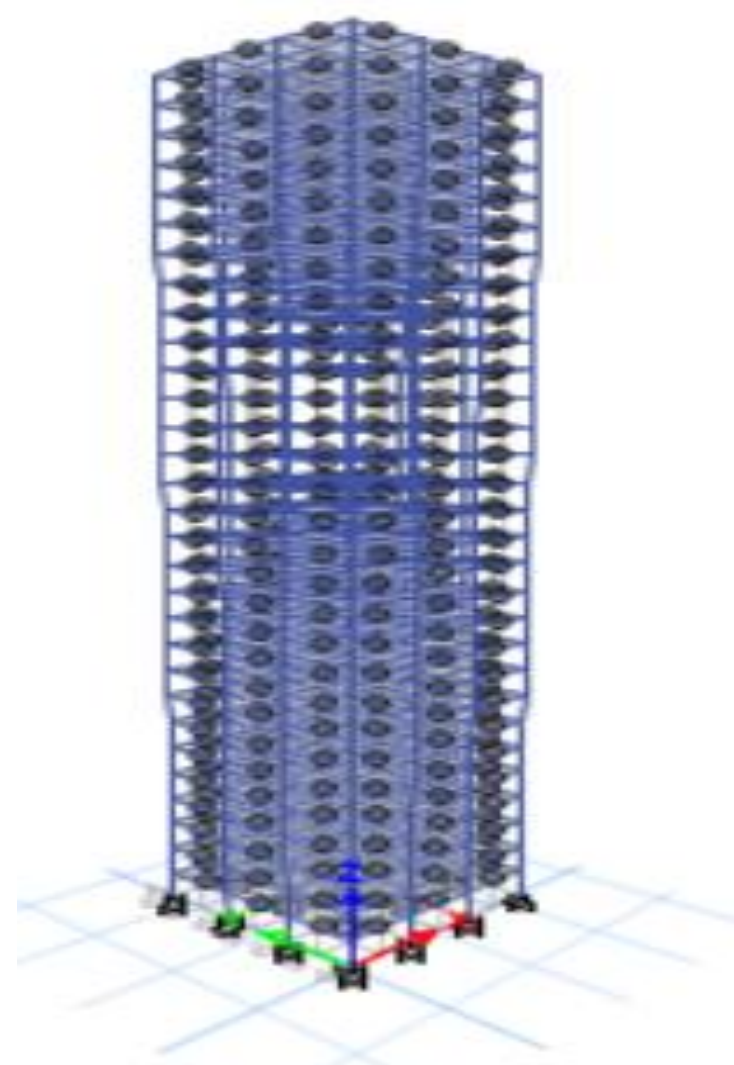

Figure 2: Conventional System

\section{b. Shear Wall Structural System}

Shear wall act as a panel for horizontal loads, in the model shear wall, is assigned at all corners of the building from top to base of the structure (Figure 3). 


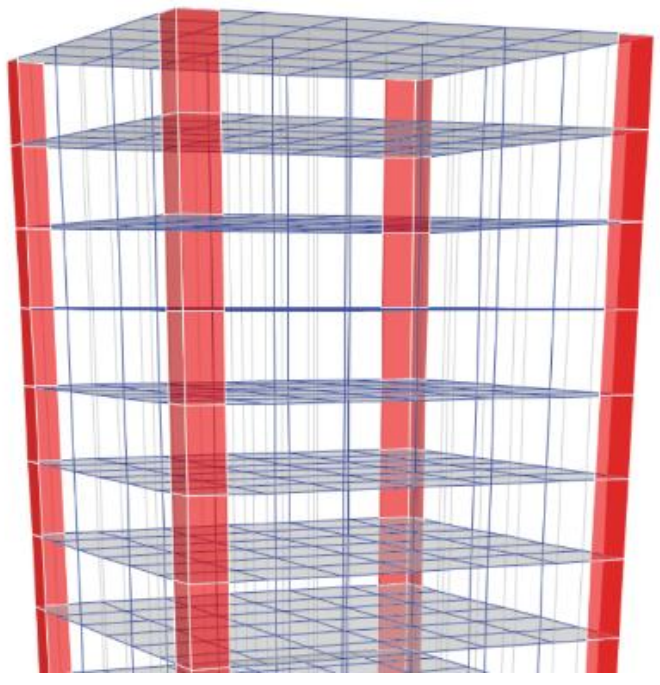

Fig. 3: Shear Wall System

\section{c. Truss Belt And Outrigger System}

Truss belt (Figure $4 \& 6$ ) and outrigger (Figure 5) which is provided around the building are tied to the core structure, where the truss belt is provided at the top base and middle of the structure and outrigger is provided at the economical height of the structure to obtain best results [19-20].

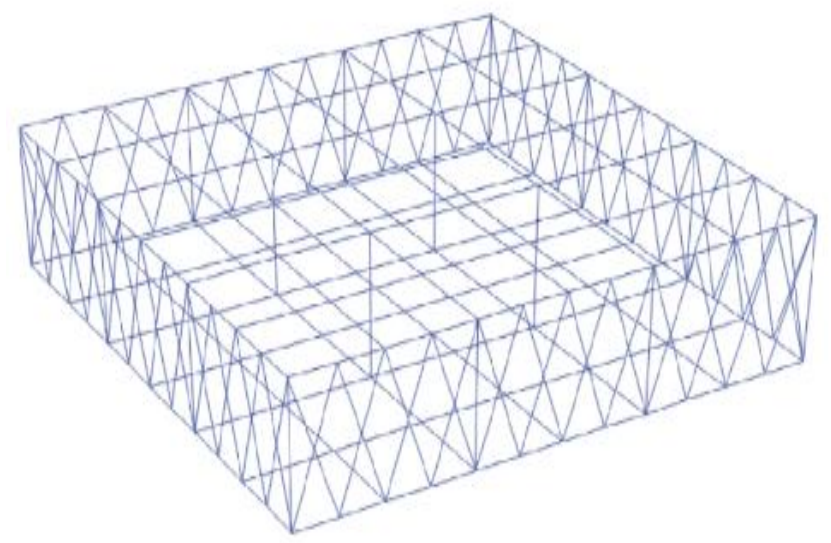

Fig. 4: Truss Belt System

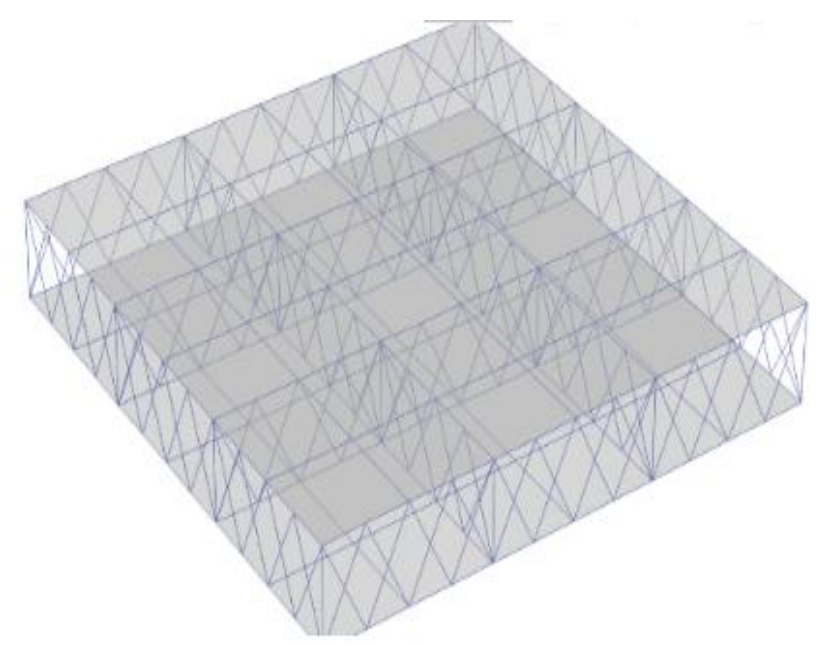

Fig. 5: Outrigger Structural System

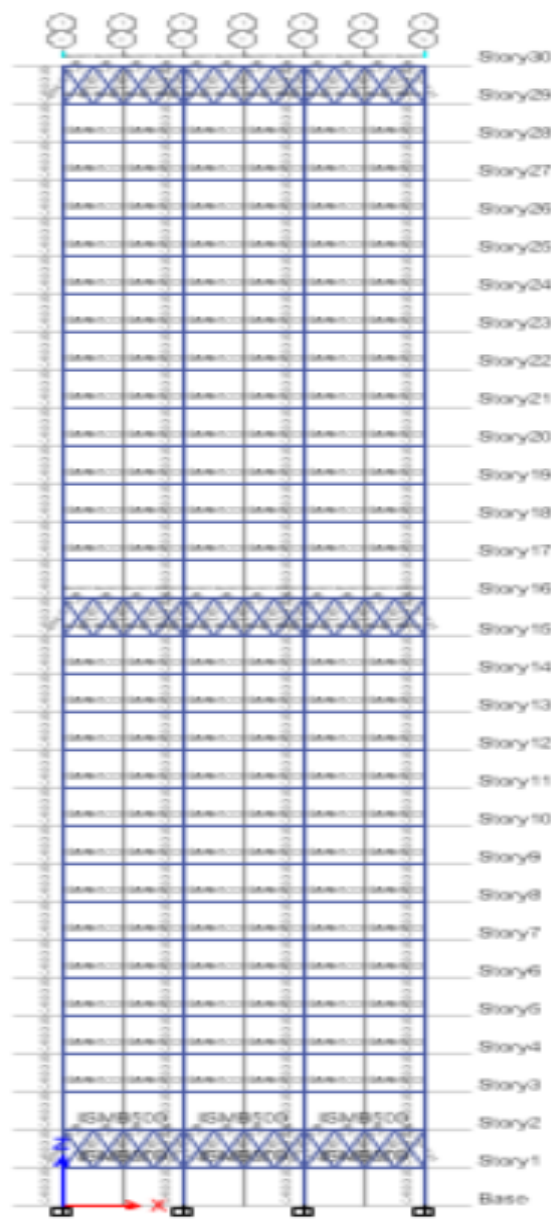

Fig. 6: Truss Belt System Elevation View

\section{d. Diagrid Structural System}

For the Diagrid structural system, the diagrids are provided at the exterior to resist lateral loads and the interior column to take up gravity loads, the optimum angle is considered as a 60-75 degree from previous studies [21-22]. To obtain the best result (Figure 7).

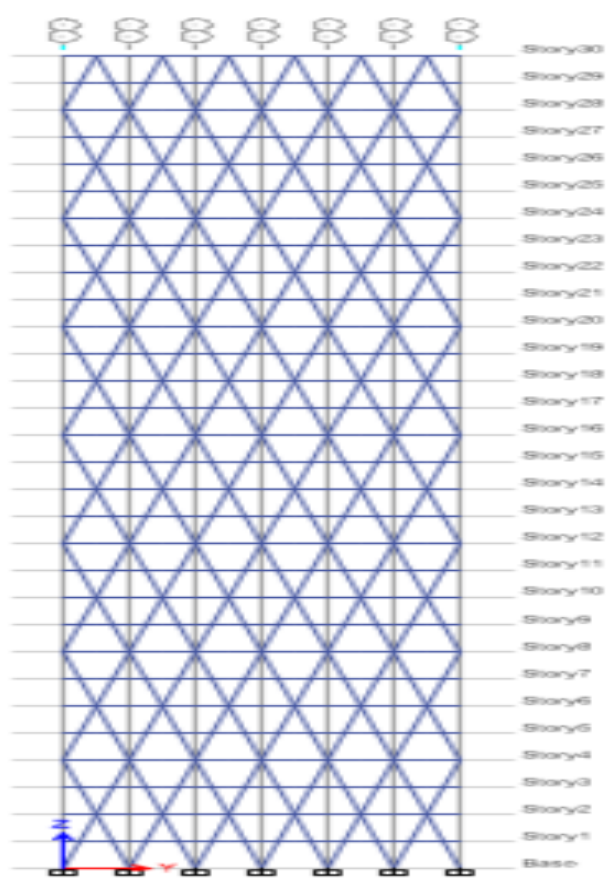

Fig. 7: Diagrid Structural System 


\section{e. Viscous damper}

Based on Viscous damper three models are analyzed to know the best performance of the structure, in the first model the dampers are placed in the middle of the structure Figure 8, the second model consists of the dampers that are located at the intermediate level of the structure up to 15 floors Figure 9, in the third model the dampers are placed from bottom floor to $15^{\text {th }}$ floor, Figure 10 as dampers to know the best result of three models and later comparing to another lateral force-resisting system.

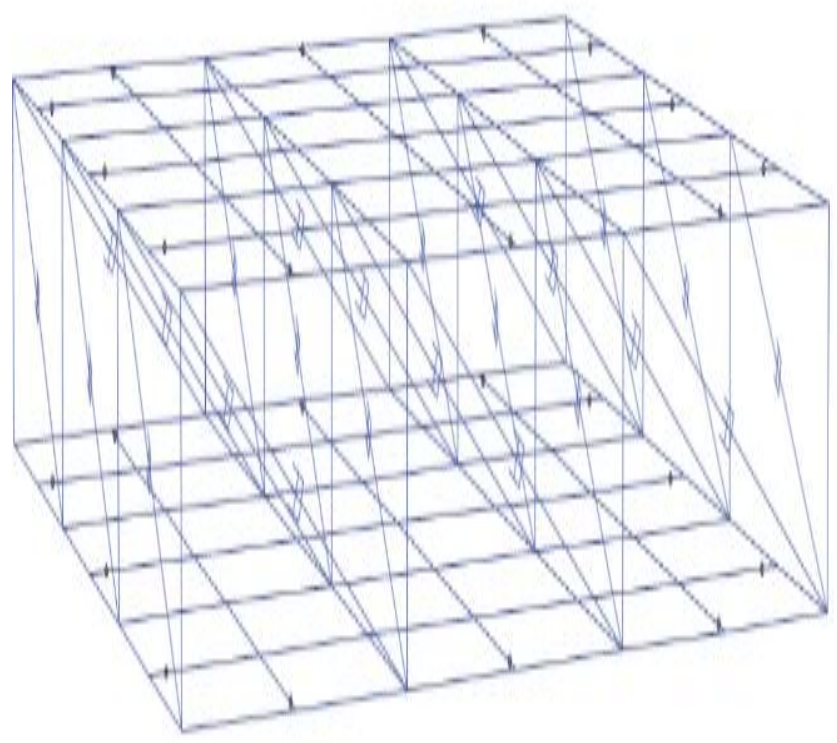

Fig 8: Viscous Damper at the Middle

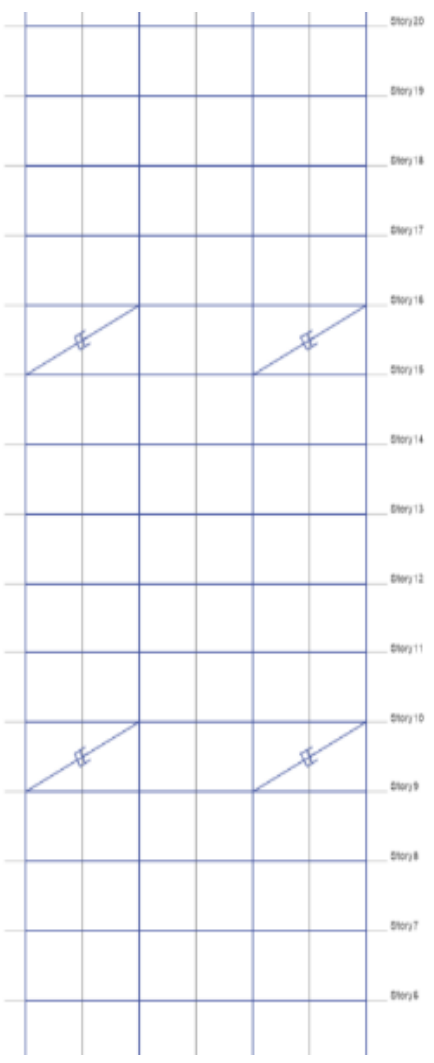

Fig 9: Viscous Damper at an intermediate system

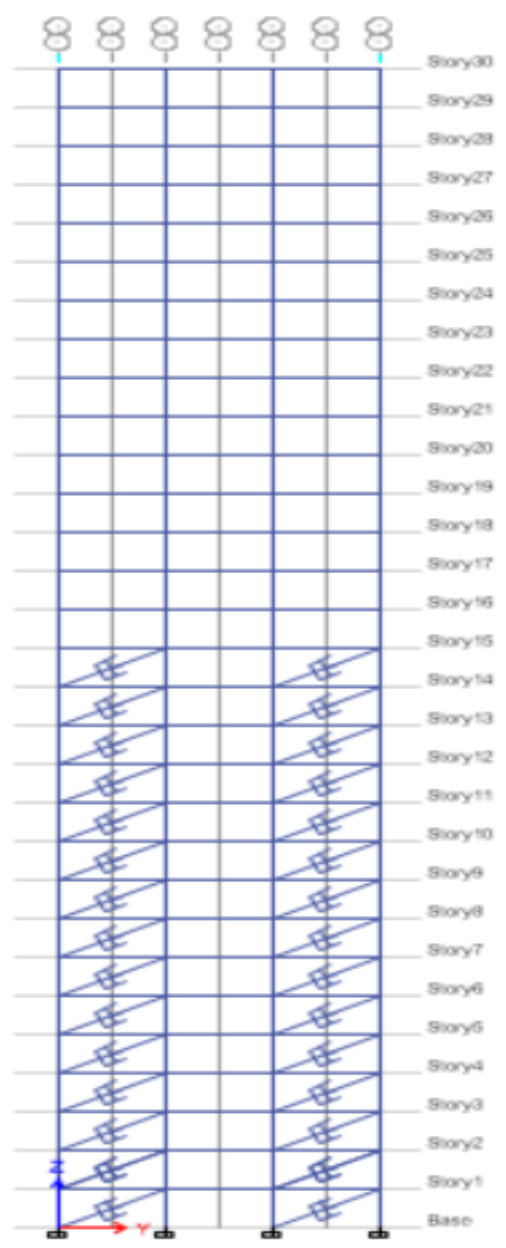

Fig 10: Viscous Damper up to $15^{\text {th }}$ floor.

\section{RESULTS AND DISCUSSION}

\section{A. Displacement}

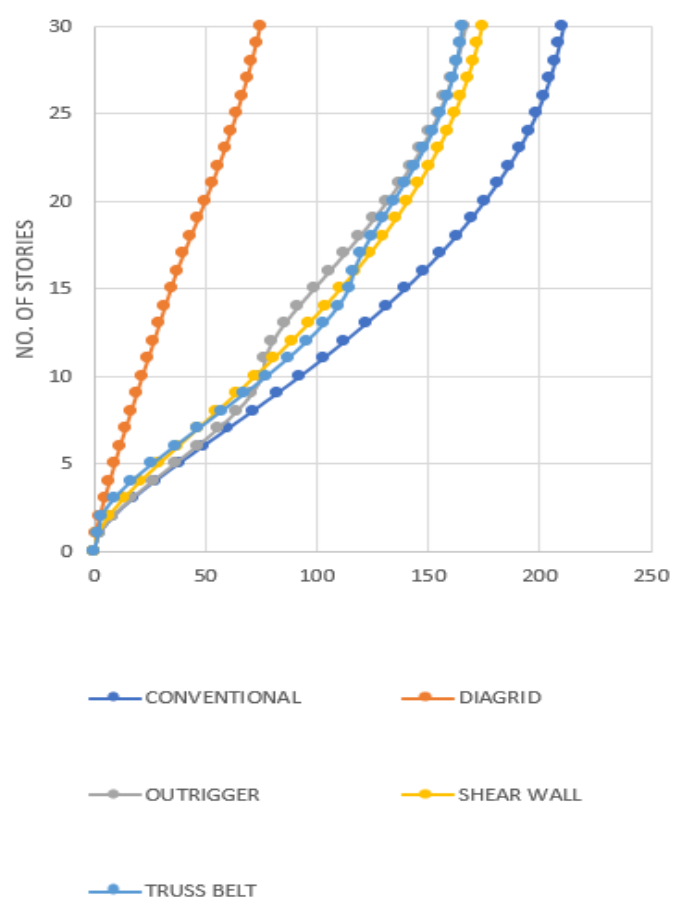

Fig 11: Maximum Displacement 


\section{Analysis of Tall Building with Different Lateral Force Resisting System}

Comparison of different lateral force resisting system like shear wall system, truss belt system, outrigger and diagrid system, diagrid structural system performs better in terms of displacement.

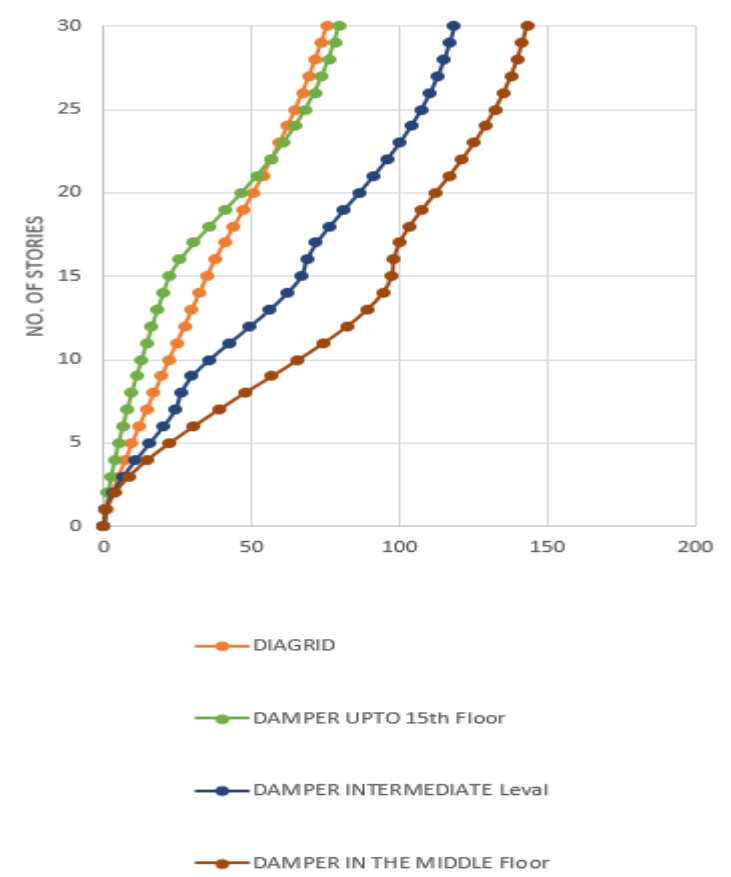

Fig 12: Maximum Displacement

- Comparison of 3 models with dampers at different locations, the model damper up to $15^{\text {th }}$ floor performs well.

- Comparison to diagrid and damper model, damper up to $15^{\text {th }}$ floor performs better in the intermediate $\left(12^{\text {th }}\right.$ to $18^{\text {th }}$ ) storey displacement, but for top storey displacement diagrid system performs slightly better.

B. Drift

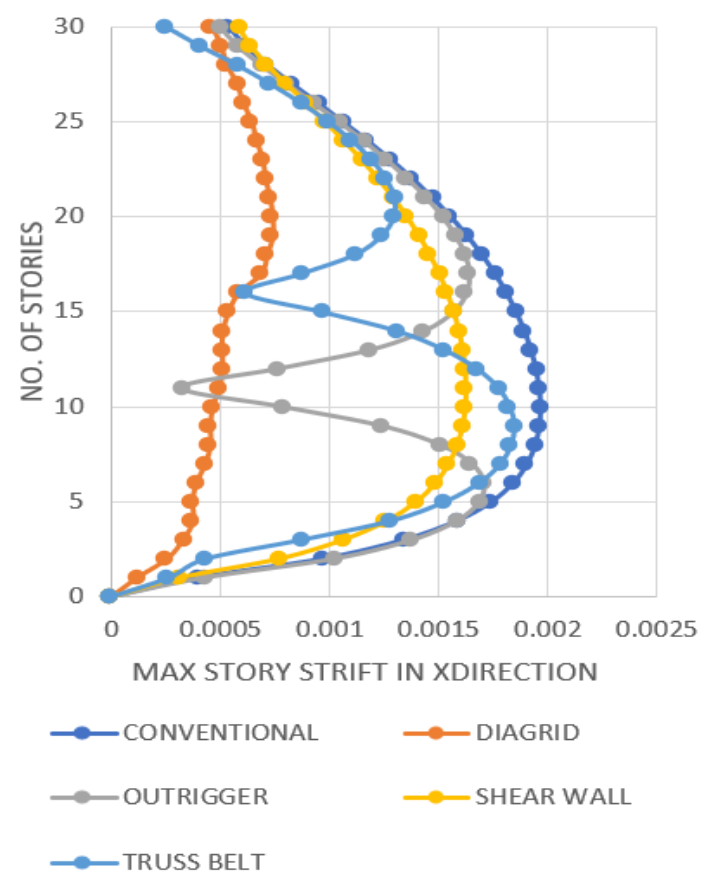

Comparison of different lateral force resisting system like shear wall, truss belt, outrigger and diagrid, diagrid structural system performs better in terms of drift.

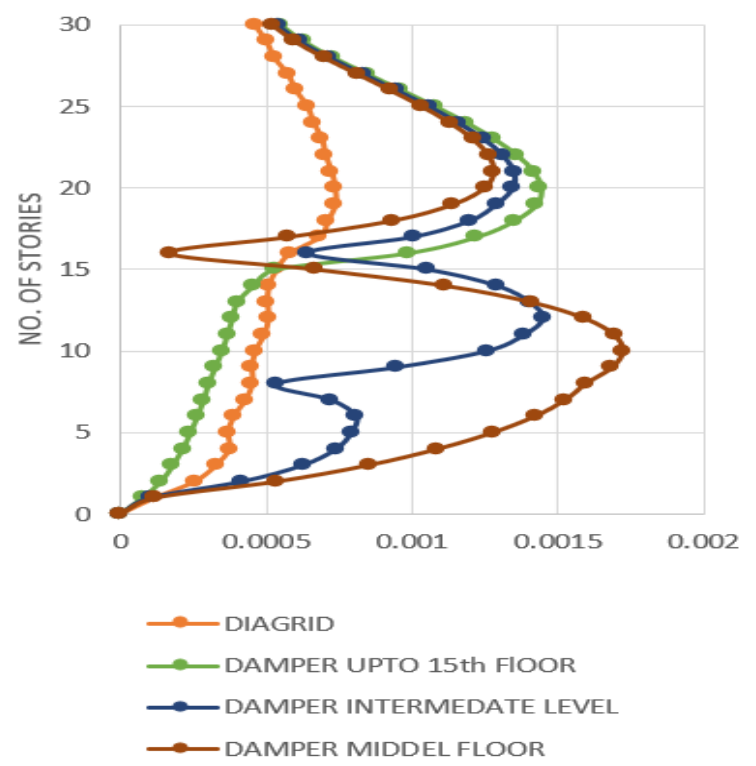

Fig 14: Maximum Drift

- Comparing the 3 damper models which are located at different locations, damper in the middle floor performs better,

- Comparing to the diagrid and damper, damper in the middle floor performs better in the inter storey drift while in the top storey diagrid performs better.

\section{Time Period}

\section{TIME PERIOD INSECONDS}

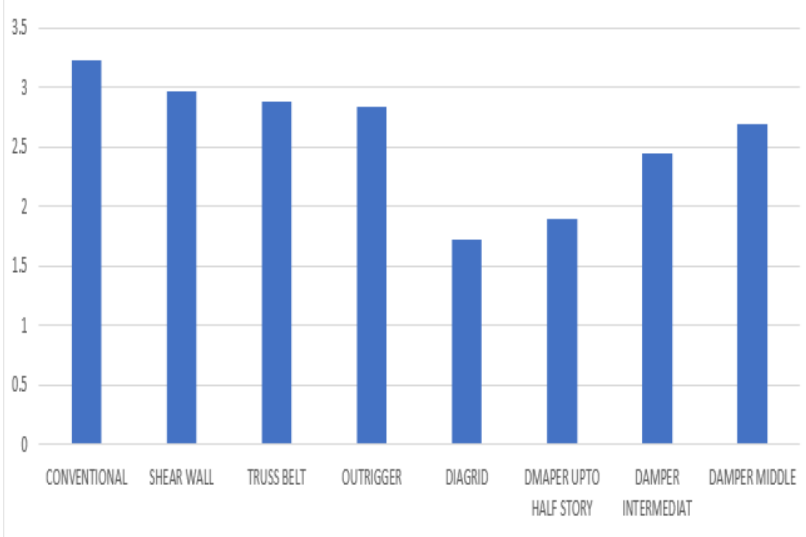

Fig 15: The time period in seconds.

By analyzing the models using the response spectrum method in the first mode the diagrid gives a lesser time period, when compared to the other structural system.

Fig 13: Maximum Drift 


\section{Consumption of Steel}

When optimizing all the models for best performance the shear wall structure consumes less steel when compared to other models.

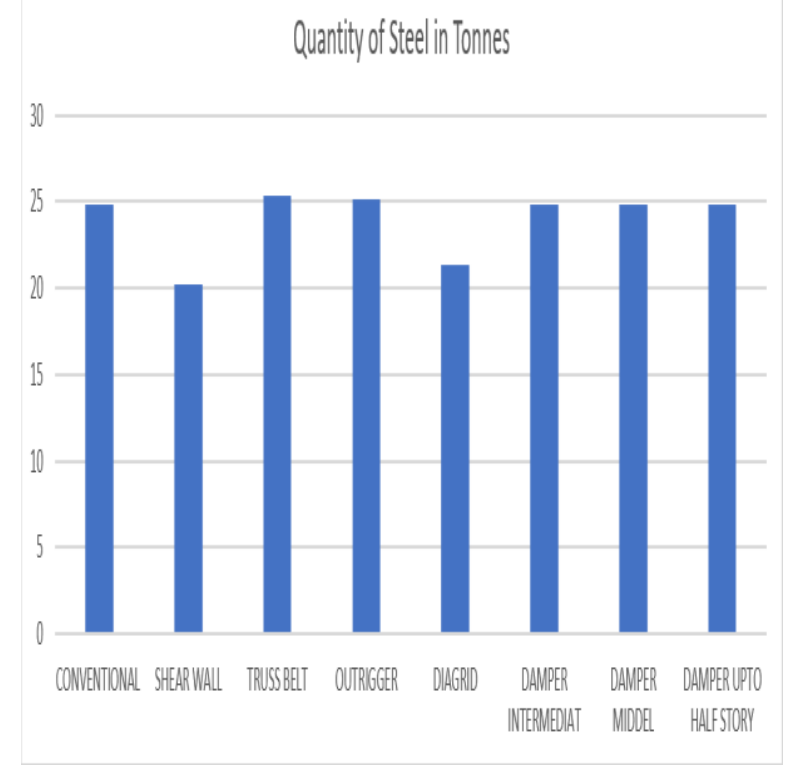

Fig 16: Consumptions of steel.

\section{CONCLUSION}

The following conclusions were drawn from the present study:

- Comparing the shear wall system, truss belt system, outrigger system and diagrid structure system, Diagrid performs better in terms of displacement, drift, and time period.

- Comparison of 3 models with dampers at different locations, the model damper up to $15^{\text {th }}$ floor performs well in terms of displacement and middle story performs better in terms of drift.

- Comparison to diagrid and Viscous damper model, viscous damper which are provided up to $15^{\text {th }}$ floor performs better in the intermediate floor, $\left(12^{\text {th }}\right.$ to $\left.18^{\text {th }}\right)$ in terms of storey displacement, but for top story displacement diagrid system performs slightly better. In terms of story drift damper in the middle floor performs better while in the top story diagrid performs better.

- When compared to conventional to other structural system considering Displacement, the Shear Wall gives $17 \%$ of the best result, Truss Belt gives $21 \%$ result, Outrigger gives $21 \%$ result, diagrid gives $64 \%$ result, Damper at middle gives $30 \%$, Damper at intermediate level gives $42 \%$ result and Damper at half story gives $61 \%$ result.

- When considering Drift, the Shear Wall gives $17 \%$ of the best result, Truss Belt gives $7.1 \%$ result, Outrigger gives $60 \%$ result, diagrid gives $76 \%$ result, Damper at middle gives $11.48 \%$, Damper at intermediate level gives $69 \%$ result and Damper at half story gives $82 \%$ result.

\section{REFERENCES}

[1]Ali. Mir M \& Kyoung Sun Moon,2007. Structural developments in tall buildings: current trends and feature prospects. Architectural science review, vol 50.3 , p 205-223.

[2] Alam,2017. Innovative Structural Concept \& Solution for Mega Tall Buildings Applied to One Kilometer Skyscraper, Open Access Library Inc. Vol 4,e3459.

[3]Chandrasekar, Karthikeyan. K, Thangakathiravan.T,G.A.,P.R.,2015. Planning and Structural Analysis of Trophy Shape Skyscraper, vol 0, Issue 03.

[4] CTBUH Council on Tall Buildings and Urban Habitat (2016), https://www.ctbuh.org/resource/height.

[5] Skyscraper Center, (2016). http://www.skyscrapercenter.com/building/capital-gate -tower/3172.

[6] Raju and Readdy, S.R, 2019. Dynamic analysis of regular and irregular high-rise buildings under the influence of shear walls by using ETABS. Journal of applied science and computations, vol 6 issue 2.440-448.

[7] Bhavsar, Rathva, S.B, D.P, 2019. Optimization of G+7 Storeyed Rcc Building with Different Positioning of Shear wall. International journal of advanced engineering and research development 6, Special Issue 01.

[8] Kala,L., Mangulkar. M, and Jain. I, 2017. The use of outrigger and belt truss systems for high rise buildings. International Journal of Civil Engineering and Technology, vol 8, issue 7.

[9] Khanorkar.A.A, Mr. S. V. Denge ,2016. Belt Truss as Lateral Load Resisting StructuralSystem for Tall Building: A review.Global Research and Development Journal for Engineering, vol 2, Issue 10.

[10] Tavakoli,Kamgar.R, R .R,2019. Seismic performance of outrigger-belt truss system considering soil-structure interaction, international journal of advanced structural engineering (https://doi.org/10.1007/s40091-019-0215-7).

[11] Ganatra.V.P, Jhummarwala.R.A, Dr. Parikh.K.B.,2017. Study on Behaviour of Outrigger System on High Rise Structure by Varying Outrigger Depth,.International Journal for Research in Applied Science \& Engineering Technology, Vol 5, issue 9., pp:1-16

[12] Shah, Gore .N.G.,2016. Review on Behavior of Outrigger System in High Rise Building. International Research Journal of Engineering and Technology, vol 03 , Issue 06. 
[13] Somvanshi,T.R, Kolase,P.K, V. R. R,2019. Comparative analysis and design of diagrid structure and orthogonal structure. International Journal of Engineering Development and Research. vol 7, issue 3, pp. 2007-18.

[14] Moon (2016), Diagrid System for Structural design of complex-Shaped Tall Building.The Twelfth East Asia-Pacific Conference on Structural Engineering and Construction. Vol 5, No 4, 243-250.

[15] Kachchhi.M. J, S.V.M, V.B.P,2019. Comparative study of Diagrid structure with other structural systems for tall buildings. Global journal of engineering science and researches. ISSN 2348-8034.

[16] Lee, U.S, and Shin,2010. Optimized Topology Extraction of Steel-Framed DiaGrid Structure for Tall Buildings. International Journal of Steel Structures, Vol 10, No 2,157-164.

[17] Cetin, Aydin.E., Ozturk.B.,2019., Optimal Design and Distribution of Viscous Dampers for Shear Building Structures Under Seismic Excitations. Journal frontiers in Built Environment, Vol 5, Article 90.

[18] Infanti, Robinson.J.,Smith.R., 2008. Viscous Dampers for High-Rise Buildings.The $14^{\text {th }}$ World Conference on Earthquake Engineering.

[19] Nanduri.R.K., Suresh.B, Hussain.I., 2013. Optimum Position of Outrigger System for High-Rise Reinforced Concrete Buildings Under Wind and Earthquake Loadings. American Journal of Engineering Research, vol 02, Issue 08.pp-76-89.

[20] Parekh, Dhandha.K.J,2016. Study on position of outrigger system in tall structure. Journal of Emerging Technologies and Innovative Research, vol 03, Issue 05.

[21] Milana, Olmati.P, K. G, F. B,2015. Ultimate Capacity of Diagrid System for Tall Buildings in Nominal Configuration and Damaged State. RPeriodica Polytechnica Civil Engineering 59(3),pp.381-391.

[22] Szolomicki.J, Szolomicki.G.H, 2017.Application of the diagrid system in modern high rise buildings. International Journal of Advances in Science Engineering and Technology,volume-5, issue-3.

\section{ABOUT THE AUTHORS}

Karthik, A. is the student of M.Tech Structural Engineering in the Department of Civil Engineering, Amity School of Engineering and Technology, Amity University Haryana, India.

Ankit Batra, is working as Assistant Professor, Department of Civil Engineering, Amity School of Engineering and Technology, Amity University Haryana, India. His area of specialization includes design and analysis of structures. He is competent in various software skills such as ETabs, STAADPro to name a few. He has published various papers in journals of national and international repute.

Sakshi Gupta, is presently working as Assistant Professor, Department of Civil Engineering, Amity School of Engineering and Technology, Amity University Haryana, India. Her areas of interest includes construction technology and management, BIM, concrete technology, Soft computing techniques in Civil Engineering applications and sustainable construction. She has published more than 40 research articles, paper, book chapters and books of National and International repute. She is the editorial as well as reviewer board member of many international journals. 